\title{
Information Content in Dividend Announcements, a Test of Market Efficiency in Malaysian Market
}

\author{
Ali Sheikhbahaei ${ }^{1}$, Mohd. Hassan Mohd. Osman ${ }^{1} \&$ Ismail Abd Rahman $^{1}$ \\ ${ }^{1}$ International Business School, Univercity Technology Malaysia (UTM-IBS), Kuala Lumpur, Malaysia \\ Correspondence: Ali Sheikhbahaei, International Business School, Univercity Technology Malaysia (UTM-IBS), \\ Lvl 15, Yayasan Selangor Bldg, Jalan Raja Muda Abdul Aziz, 50300 Kuala Lumpur, Malaysia. E-mail: \\ asheikhbahaei2@live.utm.my
}

Received: August 22, 2012

Accepted: October 10, 2012

Online Published: November 7, 2012

doi:10.5539/ibr.v5n12p38

URL: http://dx.doi.org/10.5539/ibr.v5n12p38

\begin{abstract}
This study investigates the market reaction to the changes in dividend announcements at the Malaysia stock exchange formally called Bursa Malaysia. Data is gathered for a sample of 356 dividend announcement made by 138 firms pined in the main market between the years 2008 to 2011. The results show that the market reacts positively to dividend increasing stocks but no significant react to the constant dividend or the decreasing group of dividend announcements. It was also observed from the information in a day prior to the announcement day that there is a probable leakage of information by the excess access to the insider information of the firms.
\end{abstract}

Keywords: dividend announcements, signaling, dividend policy, market efficiency, information content of dividend

\section{Introduction}

Investors are always seeking for optimizing their profit due to trading securities thereby, the more efficient market the best decisions could be made by all participants in security trading. Additionally, most firms are following the residual policy to maximize the shareholders value but, variances in earning and investment opportunities could be visible by increasing or decreasing dividend figures in different periods. Although the dividend policy is still an unsolved puzzle, but a plenty of researches have tried to come out with its different pieces. Any changes in dividends occurred by the firms dividend announcements may not be seen in the same light by the investors that have the equal access to the insider information of corporate in an efficient market, despite this, any focuses on the effect of dividend changes on share value have contribution to stock trading decision made by the investors. The information content of dividend can reveal the adjusted reaction from the market side to the stock price in a favor of market efficiency. Malaysia as an emerging market has experienced turbulence during the Southeast Asia financial crisis and its governments have been tried to push the capital market to the efficiency edges and yet it is subjected to investigate the reasons and the drivers to be an efficient market. Few studies has been done to find the information content of dividend associated to the earnings and dividend figures which regularly were announced closely but this study is specifically dealing with the dividend announcement including interim and final cash declared to be paid. The uniqueness of this study is to deal with the emblems of any probable information leakages very close to the announcement day that might reveal the excess access from the investors to the insider information of the firms. The next chapter discusses the relevant literature which will be followed by the methodology and the methods of data gathering. Section 4 discusses the empirical results. Finally, section 5 goes over the main findings of the study and concludes.

\section{Literature Review}

\subsection{Market Efficiency}

Since Fama firstly applied the concept of Efficient Market Hypothesis (EMH) on stock market in 1970 it has been generalized all over the other asset markets in recent years and many economists have demonstrated its different applications. Basically the function of the capital market is to allocate the ownership of capital stock in any given economy. A perfect situation is happened when a market signals accurately for resource allocation and in such market, investors have a variety of choices among securities that reflect all available information and firms can clearly make investment-production decisions, the market in this perfect situation is called efficient by Fama 
(1970). In general the statement of efficient is used by the economists while they consider the stock prices and stock returns as the outcomes of supply and demand in a competitive circumstances (Keith Cuthbertson, 2005).

The three type discriminated market efficiency levels according to the characteristic of information returned to the stock prices and each of them differed in how to implicate on security returns. Reilly (2006) described that the market reflects just to the historical prices, rate of returns, trading volume data and other previous market-generated set of information and it reveals the weak form of market efficiency. The semi-strong form of market efficiency asserts that the set of information in the relevant time contains all relevant information including historical price records or returns variation that is available in public, therefore the security price will react to all public information including, earnings and dividend announcements, technological breakthroughs, rights issues, board resigns or changes, price-to-earnings ratio, dividend yield ratios, price-book value ratios, political and economic news, etc. Fama (1991) found that there is no gain by analyzing the information that everybody knows, the market has already adjusted itself to the released information. Consequently no analyst including fundamental and technical, can help investors to earn above average risk adjusted return until the investors have the access to inside information of the firms to collect abnormal returns. Strong form of market efficiency states that the relevant information contains both private and public information which security prices could reflect all. The basic assumption of this model conveys no monopolistic access for any level of investors to the information of stock valuation. The result would be no excess risk-adjusted return for any specific group of investors. Neither technical and fundamental analysis nor private information can provide least value once the information is raised. Additionally, even the board of directors and managements are not able to make excess return from the private information that they hold.

Reilly (2006) demonstrated three main assumptions that make the foundation of market efficiency: (1) Assume a crowd of high-profit seeker participants analyses and assess securities, each acting separately and independently. They are rational investors and adjust their portfolios rapidly to any new released information. (2) The timing and characteristic of information used to be randomly and there is independence for each announcement. (3) Security prices are adjusted rapidly by profit maximizing investors to imitate the consequences of new information. In parallel with Ross (2006), there is a rivalry between investors in the way of rapid adjustment of security prices.

\subsection{Information Content}

In a developed theoretical model of corporate dividend behavior, having the managers' perception about their firms', Lintner's (1956) initiating proved that current dividend is depended to future earning as long as it is related to current and past. Assuming the perfect capital market atmosphere, Miller (1961) demonstrated that there is no relation between value of a firm and dividend payout ratio. Furthermore, they recommended that the market value of the firm is relied on future optimal earning not on current figures. Thus, if fleeting and permanent components are within earning figures, and if dividends payout depends on the previous data, then dividends would be treated as a proxy for estimated future earning and the surrogate relationship could declare the outcome of the related cross-sectional studies. This is labeled "the information content of dividend" by Miller and Modigliani (1961) for the first time in term of information content hypothesis. Generalizing more terms in illustrating the information hypothesis, they declare that there would be good reasons for investors to deal with the dividend change as a change in management's view of firm's future perspective when they are suppose to establish a payout policy of dividend.

Fama (1969) studied the process in which stock prices adjusted to the information within the stock split. In the paper, the attention concentrated on the behavior of cumulative average residuals for increasing and decreasing dividends in a few months before split dates. This study demonstrated that the market is "Efficient" in term of rapid adjustment to new information. In another study, using quarterly data, Pettit (1972) tried to come out with more evidence about the validity of efficient market hypothesis by estimating the speed and accuracy with which indicators adjust to the information embedded in announcement of dividends. As a result, he suggests that a quick reaction is derived from a considerable change in dividend and vice versa. He also suggested that dividend announcements convey information beyond that already revealed in simultaneous earnings number. Bhattacharya (1979) proved the signaling hypothesis but with some adjustments in assumption which claimed imperfect information access for the investors about the profitability of the firm and higher tax rate for dividends than the capital gains. He found that firms are likely to pay dividends as a signaling tool to convey the future cash expectations despite the tax disadvantages of paying dividends.

In another study, Aharony (1980) aimed to show the same results derive from the quarterly dividend changes as it is already convey by earning figures. They employed a different methodology from what has been used before by the dividend expectation model and three subsets of dividend changes in 149 industrial chosen firms. For the first 
time they considered the timing of dividend and earning announcement cases in which earnings announcements go before dividend announcements, and those earnings announcements follow dividend announcements. They assumed no leakage of information prior to the announcement days. The results shows normal returns for the security prices of firm's which had no change in their dividends.

John (1985) aimed to show that an excess return measured traditionally over an event period, could reveal more security return that risk unwilling investors are seeking for holding the asset over a riskier period. They tried to test the hypothesis that there is no significant difference between the mean return on days in the event window and any other probable day. The test employed both market model and the mean adjusted model having the sample of 302 dividend announcement. The results rejected the null hypothesis and shows that there is a significantly higher mean excess return over the event period. They statistically linked the higher return of security to the high risk in the same event period. Kao (1994) used a rational signaling model. They did a direct test on unexpected dividend and earning changes to investigate the information content of dividends. The results showed that the changes in dividend reflect the changes in past, present and future earning properties. Their results showed that dividend changes reflect not only managers' permanent earnings expectations but also unexpected changes in earnings outlooks.

Benartzi and Michaely (1997) tried to find the immediate and long-term reactions of market by using several samples of cash dividends initiations and omissions. In a three days event window for immediate effect and one month period for long-run reaction, they calculated the excess returns of the stocks by using a bye-and-hold abnormal returns (BARs) method (Fama, 1970). They found a positive immediate impact and continuous rising by dividend initiating and a drift in negative direction results for dividend omission. They found a stronger result for omission in long-term than initiating. They argued that there is less information about future earning meanwhile the market is responding to dividend changes. Taking more than seven thousand dividend announcement in a 22 years period, they tried to demonstrate whether any information about future earning was conveyed by changes in dividends or not. The results did not show much positive association between dividend changes and future earnings. This was in parallel with the empirical study of Watts (1973). Furthermore they tested the Lintner's theory and found the same results that information content of dividends are more likely to the past and current firm's earning rather than the future earnings trends. Finally they suggested that the Lintner's results are still is the best explanation of dividend policy available.

Dyl and Weigand (1998) studied the risk factor of the firms in which initiated the cash dividends. They investigated the information about the firm's lower risk that were conveyed to the market by dividend initiations and suggested it as risk-information hypothesis. Using the Fowler-Rokre modified methodology for calculating betas which is the aggregated coefficient method proposed by Dimson (1979). With pre and post announcement beats, they tried to find whether dividend announcement is followed by a change in systematic risk. The results of their empirical study demonstrate that there is significantly lower risk in the year after the initiation of the dividends.

High proportion of the empirical studies about the signaling hypothesis and information content of dividend were done in the context of United States by gathering the information of New York Stock Exchange (NYSE) but numbered of studies were involved in some other markets and other developed countries such as Germany, Japan, UK to test the similarities of the results derived from the NYSE. In one of these papers, Dewenter (1998) compared dividend policies of the firms in U.S and Japan. They partitioned the data of Japanese market and examined the association between dividend changes and security returns. The results show a smaller price reaction to dividend omission and initiation than the U.S firms. They also found that the Japanese firms have less reluctant to omit and cut dividends, and their dividends are more correlated with their earnings changes. Conroy (2000) (Conroy, Eades, \& Harris, 2000) investigated the managers simultaneously announcement of dividend and earnings regarding to the current year's dividends and earnings as well as future forecasts of dividends and earnings. Consistent with Denwenter (1998) current dividend surprises have no significant impact on security returns in Japan. Gunasekarage (2002) tried to test the hypothesis that the firms which increase their dividends do not outperform their dividend decreasing equivalent during the years after increasing dividend with respect to financial performance. They tested a sample of 1787 company in UK within 14 years and the results rejected the hypothesis. In case of other developed countries, Vieira (2007) tested the classic dividend signaling hypothesis in the EURO zone and she found no support for positive association between changes in dividend and stock price for French firms and only a week relationship for Portuguese and UK firms. In a recent paper, Altiok-Yilmaz and Selcuk (2010) studied the effects of cash dividend payment on security returns and the volume stock exchange trading in Istanbul Stock Exchange. The results shows an increasing trend sessions before cash dividend payments, prices have a slightly fall on the ex-dividend day and declining trend the day following the payment date. The trading 
volume also shows considerable upward trend before the payment day and a stable volume of trading accurse after the payment date. Their findings support the hypothesis of positive effect of cash dividend on stock market and the price-volume reaction model which can be applied on the payment dividend date. In a very recent paper, (Altiok-Yilmaz \& Selcuk, 2010) investigated the market reaction to dividend change announcements at the Istanbul Stock Exchange. Testing the sample of 184 announcements of 46 firms during three years prior to 2008 they employed the event study methodology and suggested that the market reacts positively to dividend increases, negatively to dividend decreases and in neutral to no changes in dividends and the results were consistent with the signaling hypothesis. They concluded the pre-event leakage of information discussion for the samples with declining dividend samples.

\subsection{Malaysia}

Standing as an emerging market in the south-east of Asia, Malaysia is a fast growing market "setting out to transform its economy through industrialization to become a fully developed country by the year 2020" (Al-Twaijry, 2007). Malaysia has not experienced a specific procedure or policy in term of dividend payment meanwhile, the firms have all the responsibility and freedom to manage the frequently and the amount of dividend's pay out in the related financial year following the companies Act 1965. "No dividend shall be payable to the shareholders of any company expect out of profits or pursuant to section 60" Stated in section 365. Pandey (2001) investigated among different types of firms including construction, consumer products, industrial products, plantation, and property and trading or services to come out with the effective variables on dividend payout. Results shows relevancy to the type of industry on payout ratios. She also suggests that the Malaysian companies consider the earning changes for their dividend payout. Aivazian (2003) studied the dividend payout ratio among eight emerging market including: Turkey, Pakistan, South Korea, India, Malaysia, Zimbabwe, Jordan, and Thailand apparently compared them with the US market. The results show that the firms in those markets tend to payout just about their matching firms in US and surprisingly Malaysia experienced the closest range to US with a median dividend yield of 2 percent.

Rafiq (2008) studied annual earnings and dividends from randomly 60 firms during 1975 to 1989 . They tested two models: in the Simple Model they tried to find the relationship between changes in current dividends and changes in current and past earning figures. The second model that they employed was Lintner's model which investigated the changes in current dividend associated to changes in present and past earning and dividend. Simple Model indicated that increasing in earning is related to the decision to increase dividends and the declining of dividends is following the decreasing trends in earning numbers. They suggested that firms are having long-term target dividend payout which is composed by their earnings performance. In a recent paper, Puah et al. (2008) studied the characteristics of dividend-paying of 100 firms in Bursa Malaysia. By using the coefficient of correlation method, the study covered the variables such as growth opportunities, profitability, size, firm risk, and leverage and share distribution. The results did not support the signaling theory as there was no relationship between dividend increases and performance in future earnings forecasts. They found the dividend-paying companies shining as more profitable, matured, less risky, and stable as compared to non dividend-paying firms.

Yip (2010) examined the market reactions to 1088 dividend announcements and their interaction with earning announcement between 2004 and 2008 in the Malaysian stock market by employing the market model. In some contents, the results show consistency with the dividend signaling hypothesis. The market model explored positive abnormal return following the dividend increases and unchanged announced cases. They suggest symmetry but independently influence from both dividend and earning announcement on security price by combining dividend and earning announcement that happened before dividend announcements. In a very recent paper that explored in the Malaysian market, Dehghani (2011) investigated among 91 firms that distributed special dividends and tried to find the relationship between special dividend announcement and security returns in Bursa Malaysia in the period of 3 years prior to 2006. They found that special dividends convey good news to the market and investors and the positive reaction is generally obtained after special dividend announcement.

\section{Data and Methodology}

The aim of the study is to investigate in market returns to find whether dividends announcements convey information for the investors to take the results into their future portfolio considerations. To achieve the objective, an event study is employed to find the abnormal returns that the investors achieved in the chosen period around the dividend announcements. The event study methodology is based on the core assumption that states the abnormal returns occur since the communicated information to the market hold useful and fruitfully contents or the investors and security holders. In the event period, the impact of that particular event on the wealth of security holders is measured by magnitude of the abnormal performance. 
To categorize the sample announcements as Increased Dividend (ID), Constant Dividend (CD), and Decreasing Dividend (DD), the naïve model used by Aharony and Swary (1980) was employed:

$$
E\left(D_{i, t}\right)=D_{i, t-1}
$$

Where $E\left(D_{i, t}\right)$ is the expected final or interim dividend for time $\mathrm{t}$; and $D_{i}, t_{-1}$ is the amount of same type of dividend announced in time $t_{-1}$.

Increasing dividend, constant or decreasing are accordingly defined as the difference in dividend between two related following times. This naïve model is based on the assumption that managers are reluctant to change dividend in either direction unless they come out with the idea that long run prospects of the firm will be significantly changed. Some difficulties were facing the study during data gathering that slackened the process of collecting and sorting the data. The most important issue was the missed data in the Bloomberg database that might be caused by technical problem or insufficient information transmission from the board of Bursa Malaysia to Bloomberg data server. In order to tackle this failure, we need to reconsider the missed data by Market Model prediction. The sample is obtained from the Bursa Malaysia listed companies (main market) following Mackinaly (1997) specifications. The main-market listed company that regularly distributed cash dividends for the period 2008 to 2011 is selected for the propose of the study. The companies with an announcement contributed to earning, stock split or merger and acquisitions surrounding the mentioned dividend announcement are excluded from the domain of study in order to moderate the effect of other simultaneous unrelated events on the security prices. Financial firm as they are subjected to different governance and regulation are also excluded. Considering the limitation such as not regularly cash dividend payments, excluding the special dividends during the event as well as comparing model which needs the special justification to find the related comparing dividends announcements, a number of totally 138 firms is included in the sample (Plantation 9, Consumer products 23, Trading/Services 28, Industrial products 45, Reits 11, Properties 16, Construction 9). Among the verities of dividend announcements, the comparing model follows Aharony (1980) to obtain the quarterly cash dividend per share but not including extra dividend whereas the extra dividends are not common among all Malaysian firms. between different type of dividend announcements, a set of selected justified announcements (Final single tier, First and final single tier, Interim single tier, First interim single tier, Second interim single tier, Third interim single tier, Interim, final) is gathered to reveal the sample of announcements. A total number of 356 dividend announcements including increasing (122), No change (107) and decreasing (117) are studied during the period of January 2008 and December 2011. In order to fulfill the correlations of the samples, each announcement is compare to its previous same type announcement in term of performance due to the amount of dividend announcement in Malaysian Ringgit.

A three day event window is chosen from one day prior to the dividend announcement to the next day of the event. This length of window enables the study to capture any probable leaked information that might have happened very keen to the announcement day as well as the immediate effect of announcement on the stock price right the day and a day after event (Kothari, Lewellen, \& Warner, 2006). To achieve the normal return of the securities in absence of event, following Aharony (1980) this study employed 60 daily returns as the prediction period, from the day $\mathrm{T}=-63$ to the day $\mathrm{T}=-3$. The market model is used to estimate the normal return or as it is declared in the model as expected returns. The following linear time-series is expressing the market model for security $i$ in the year $j$ through period $t$.

$$
E\left(R_{i, t}\right)=\alpha_{i, j}+\beta_{i, j} \times R m_{j, t}+e_{i, j, t}
$$

$E\left(R_{i, t}\right)=$ Daily return on the security i for year $\mathrm{j}$ during time $\mathrm{t}$.

$\alpha_{i, j}, \beta_{i, j}=$ Market model factors for security i for year $\mathrm{j}$-ordinary least-squares.

$R m_{j, t}=$ Return of the market (KLCI-index) for year j during time $\mathrm{t}$.

$e_{i, j, t}=$ Error term for security $\mathrm{i}$ for year $\mathrm{j}$ at period $\mathrm{t}$.

The abnormal return will be achieved in the event window by calculating the different between the actual stock price derived from the closing prices on the date and the normal return calculated by the above market model.

$$
A R_{i, t=} R_{i, t-} E\left(R_{i, t}\right)
$$

$A R_{i, t}=$ The abnormal return on stock $i$ on day $t$

$R_{i, t}=$ Is the actual return of stock $i$ on day $\mathrm{t}$;

$E\left(R_{i, t}\right)=$ Is the expected return on the security $i$ for year $j$ during time $t$.

Finally, cumulative abnormal returns, $C A R$ over the event window from day $d=-1$ to the end day $D=+1$ is 
calculated As follows:

$$
C A R_{d, D}=\sum_{n=d}^{D} M A R^{t}
$$

Under the null hypothesis that dividend announcements have no impact on corresponding stock prices, t-statistics were used to determine the statistical significance of the abnormal returns, $A R_{i, t}$ and the cumulative abnormal return $C A R_{d, D}$.

\section{Empirical Results}

Regarding to the aim of this study, we target to the market reaction to the changes in dividends announcements. The 346 announcements by 138 firms were divided into three groups by comparing the Dividend Per-Share (DPS) for each observation at time $t$ to the previous similar DPS at any time t- 1 within the specific 4 years period from 2008 to 2011. Characteristics of three groups of announcement are Increasing Dividend (ID), Constant Dividend (CD) and Decreasing Dividend (DD) contributed to DPS $>D P S_{t-1}, \mathrm{DPS}_{t}=\mathrm{DPS}_{t-1}$ and $\mathrm{DPS}_{t}<\mathrm{DPS}_{t-1}$ respectively. As a result, 122 announcements are classified in the increasing dividend group, 107 as Constant dividend and 117 as Decreasing. Table 1 shows the results of AR analysis for the described three types of dividend announcements.

Table 1. Abnormal Returns analysis to dividend increase, Decrease and unchanged

\begin{tabular}{|c|c|c|c|c|c|c|c|c|c|}
\hline \multirow{2}{*}{ Day } & \multicolumn{3}{|c|}{ Dividend Increased $(\mathrm{N}=122)$} & \multicolumn{3}{|c|}{ Dividend Constant $(\mathrm{N}=107)$} & \multicolumn{3}{|c|}{ Dividend Decreased $(\mathrm{N}=117)$} \\
\hline & $\mathrm{AR} \%$ & t-stat & CAR \% & AR \% & t-stat & CAR \% & $\mathrm{AR} \%$ & t-stat & CAR \% \\
\hline-1 & 0.0168 & 1.447 & 0.0168 & 0.57 & 0.493 & 0.57 & 0.32 & 1.031 & 0.32 \\
\hline 0 & 0.0180 & 1.546 & 0.0348 & 0.87 & 2.792 & 1.44 & 0.01 & 0.042 & 0.33 \\
\hline+1 & 0.021 & 1.767 & 0.0554 & 0.9 & 3.338 & 2.34 & 0.60 & 3.232 & 0.93 \\
\hline
\end{tabular}

The results of the table 1 shows that there is statistically significant AR for the ID group in all three days of event window and same result for day 0 and day +1 for $C D$ as well as day -1 and day +1 for DD group. The market reacts positively to the increasing dividend as the investors considered the increasing dividend as positive signal of future optimum earning. Meanwhile, the signaling cannot be applied to the decreasing group where there is significant positive AR reflected by market during the days -1 and +1 and in parallel with Yip (2010), the signaling effect is only partially presented for the ID group. The positive significant changes for AR regarding to ID and DD in the day -1 might reveals a leakage of information in a short period before the official announcement and it can be considered as a short-term reaction linked to the event after the announcement (Kothari, et al., 2006).

In order to find the stock price reaction to three different group of dividend announcement in a specific window, the result of t-test analysis on Cumulative Abnormal Return values for these three groups is presented in table 2 .

Table 2. CAR Values for selected event windows

\begin{tabular}{lll}
\hline Type of change in dividend announcement & \% CAR & t-Statistic \\
\hline ID & 5.53 & 3.46 \\
CD & 2.34 & 0.052 \\
DD & 0.93 & 0.013 \\
\hline
\end{tabular}

As a result, for the three day event window surrounding the dividend announcement, CAR $(-1,1)$ value is positive and statistically significant for the increasing dividends group, which demonstrate the trend of investors to buy the stocks that are willing to pay more dividend than the previous period. The result for the constant dividend group is also positive but not significant and finally the result for the decreasing group is insignificant and reveals a value not significantly different from zero value.

\section{Conclusion}

This study investigated whether the dividend announcements in the forms of interim and final convey any information to the Kuala Lumpur Stock Exchange (Bursa Malaysia). Fulfilling the study, the cumulative abnormal returns and the average abnormal return were calculated by applying the event study analysis on daily data with market model adjustments on 336 dividend announcements of 138 firms during the period 2008 to 2011. A three day event window enabled the analysis to obtain the reaction of market to three types of changes in dividend announcement including increasing, constant and decreasing groups meanwhile any leakage of information one day prior to the event was considerable. Using the event study on a three day event window 
surrounding the day of dividend announcement, we found a positive reaction to the dividend increases but there was no significant relation between constant dividends announcement and the stock price. These finding are consistent with the signaling hypothesis but no negative reaction to the decreasing dividend group was found. Our result of analyzing the data that was obtained from a day prior to the event leads us to a semi strong form of efficiency where as a probable leakage of information from the insider information of the firms was considered.

\section{Acknowledgement}

We would like to thank Associate Professor Dr. Yeng Chai Lai for his comments.

\section{References}

Aharony, J., \& Swary, I. (1980). Quarterly Dividend and Earnings Announcements and Stockholders' Returns: An Empirical Analysis. The Journal of Finance, 35(1), 1-12. http://dx.doi.org/10.1111/j.1540-6261.1980.tb03466.x

Aivazian, V., Booth, L., \& Cleary, S. (2003). Do Emerging Market Firms Follow Different Dividend Policies From U.S. Firms? Journal of Financial Research, 26(3), 371-387. http://dx.doi.org/10.1111/1475-6803.00064

Al-Twaijry, A. A. (2007). Dividend policy and payout ratio: evidence from the Kuala Lumpur stock exchange. Journal of Risk Finance, 8(4), 349 - 363. http://dx.doi.org/10.1108/15265940710777306

Altiok-Yilmaz, A., \& Selcuk, E. A. (2010). Information Content of Dividends: Evidence from Istanbul.

Benartzi, S., Michaely, R., \& Thaler, R. (1997). Do Changes in Dividends Signal the Future or the Past? The Journal of Finance, 52(3), 1007-1034. http://dx.doi.org/10.1111/j.1540-6261.1997.tb02723.x

Bhattacharya, S. (1979). Imperfect Information, Dividend Policy, and "The Bird in the Hand" Fallacy. The Bell Journal of Economics, 10(1), 259-270. http://dx.doi.org/10.2307/3003330

Conroy, R. M., Eades, K. M., \& Harris, R. S. (2000). A Test of the Relative Pricing Effects of Dividends and Earnings: Evidence from Simultaneous Announcements in Japan. The Journal of Finance, 55(3), 1199-1227. http://dx.doi.org/10.1111/0022-1082.00245

Dehghani, P., \& Chun, L. S. (2011). The impact of the special dividend announcement on the stock return: the case of Malaysia. Journal of International Business Research, 10(s1).

Dewenter, K. L., \& Warther, V. A. (1998). Dividends, Asymmetric Information, and Agency Conflicts: Evidence from a Comparison of the Dividend Policies of Japanese and U.S. Firms. The Journal of Finance, 53(3), 879-904. http://dx.doi.org/10.1111/0022-1082.00038

Dimson, E. (1979). Risk measurement when shares are subject to infrequent trading. Journal of Financial Economics, 7(2), 197-226. http://dx.doi.org/10.1016/0304-405X(79)90013-8

Dyl, E. A., \& Weigand, R. A. (1998). The Information Content of Dividend Initiations: Additional Evidence. Financial Management, 27(3), 27-35. http://dx.doi.org/10.2307/3666272

Fama, E. F. (1970). Efficient Capital Markets: A Review of Theory and Empirical Work. The Journal of Finance, 25(2), 383-417. http://dx.doi.org/10.1111/j.1540-6261.1970.tb00518.x

Fama, E. F. (1991). Efficient Capital Markets: II. The Journal of Finance, 46(5), 1575-1617. http://dx.doi.org/10.1111/j.1540-6261.1991.tb04636.x

Fama, E. F., Fisher, L., Jensen, M. C., \& Roll, R. (1969). The Adjustment of Stock Prices to New Information. International Economic Review, 10(1), 1-21. http://dx.doi.org/10.2307/2525569

Gunasekarage, A., \& Power, D. M. (2002). The post-announcement performance of dividend-changing companies: The dividend-signalling hypothesis revisited. Accounting \& Finance, 42(2), 131-151. http://dx.doi.org/10.1111/1467-629X.00071

John, K., \&Williams, J. (1985). Dividends, Dilution, and Taxes: A Signalling Equilibrium. The Journal of Finance, 40(4), 1053-1070. http://dx.doi.org/10.1111/j.1540-6261.1985.tb02363.x

Kao, C., \& Wu, C. (1994). Tests of Dividend Signaling Using the Marsh-Merton Model: A Generalized Friction Approach. The Journal of Business, 67(1), 45-68. http://dx.doi.org/10.1086/296623

Keith Cuthbertson, D. N. (2005). Quantitative Financial Economics: Stocks, Bonds and Foreign Exchange. John Wiley \& Sons.

Kothari, S. P., Lewellen, J., \& Warner, J. B. (2006). Stock returns, aggregate earnings surprises, and behavioral 
finance. Journal of Financial Economics, 79(3), 537-568. http://dx.doi.org/10.1016/j.jfineco.2004.06.016

Lintner, J. (1956). Distribution of Incomes of Corporations Among Dividends, Retained Earnings, and Taxes. The American Economic Review, 46(2), 97-113.

MacKinlay, A. C. (1997). Event Studies in Economics and Finance. Journal of Economic Literature, 35(1), 13-39.

Miller, M. H., \& Modigliani, F. (1961). Dividend Policy, Growth, and the Valuation of Shares. The Journal of Business, 34, 411-433. http://dx.doi.org/10.1086/294442

Pandey, I. M. (2001). Corporate Dividend Policy and Behaviour: The Malaysian Experience. SSRN eLibrary.

Pettit, R. R. (1972). Dividend Announcements, Security Performance, and Capital Market Efficiency. The Journal of Finance, 27(5), 993-1007. http://dx.doi.org/10.1111/j.1540-6261.1972.tb03018.x

Puah, C. H., Entebang, H., \& Voon, S. L. (2008). Corporate crime announcement effects on stock perfoprmance: an empirical stydy in malaysia. Journal of Economic cooperation, 29(2), 15-28.

Rafiq, M. (2008). The Determinants of Capital Structure of the Chemical Industry in Pakistan. The Lahore Journal of Economics, 13(1), 139-158.

Reilly, F. K. B., \& Keith, C. (2006). Investment Analysis and Portfolio Management. Thomson/South-Western. International Business Research, 3(3), 126-132.

Vieira, E. F., \& Raposo, C. C. (2007). Signalling with Dividends? The Signalling Effects of Dividend Change Announcements: New Evidence from Europe. SSRN eLibrary. http://dx.doi.org/10.2139/ssrn.955768

Watts, R. (1973). The Information Content of Dividends. The Journal of Business, 46(2), 191-211. http://dx.doi.org/10.1086/295525

Yip, P. P. (2010). Share Price Reaction to Dividend Announcements and the Interaction with Earnings Announcements in the Malaysian Stock Market. Asian Journal of Business and Accounting, 3(2), 101-120. 